\title{
Suplementasi obat cacing, sirup Fe, dan vitamin C meningkatkan kadar hemoglobin dan status gizi balita di Kupang
}

Siti Romlah', Hamam Hadi², M. Juffrie ${ }^{3}$

\begin{abstract}
Background: The prevalence of having intestinal worms among malnourished children under five as the cause of anemia at the Province of Nusa Tenggara Timur is still relatively high. Efforts to minimize intestinal worm infection and anemia and to increase nutrition status of malnourished children under five who get recovery complementary foods are made through supply of intestinal worm drugs, Fe syrup and vitamin C.

Objective: To identify the effect of the supply of intestinal worm drugs, Fe syrup, and vitamin $C$ supplementation to the increase of haemoglobin $(\mathrm{Hb})$ level and nutritional status of malnourished children under five who got recovery complementary foods.

Method: This was an experimental study with factorial design. Subject of the study were malnourished children under five of 1-3 years of age at Kupang Municipality. There were as many as 128 samples divided into 4 experiment groups. The group got pyrantel pamoat intestinal worm drugs $125 \mathrm{mg}(n=32)$, Fe syrup + vitamin $C(n=32)$, and placebo ( $n=32)$. $\mathrm{Hb}$ level was measured using "Hemocue-B Hemoglobin photometer", intestinal worm infection was observed through facces of the subject to identify the presence of worm eggs. Statistical analysis used t-test to identify the relationship before and after the supply and ANOVA to find out the difference in the effect of the supply among the groups.

Result: After 3 months, the supply of the intestinal worm drugs before intervention had significant effect to intestinal worm infection status among the group with intestinal worm drugs and the group with intestinal worm drugs, Fe syrup + vitamin $\mathrm{C}$. The highest increase of $\mathrm{Hb}$ level was found in the group with intestinal worm drugs, Fe syrup + Vitamin $C$ with average increase as much as $1.2 \mathrm{~g} / \mathrm{dL}$. Average increase of weight among the groups was $0.3 \mathrm{~kg}$. Increase of Z-score significantly affected index of weight/age and weight/height.

Conclusion: The increase of $\mathrm{Hb}$ level significantly affected changes of nutritional status increase among the experiment groups.
\end{abstract}

KEYWORDS: intestinal worm drugs, Fe syrup, vitamin C, Hb level, nutritional status, malnourishment

\begin{abstract}
ABSTRAK
Latar Belakang: Prevalensi kecacingan pada balita gizi buruk sebagai penyebab anemia di Provinsi NTT masih tinggi. Upaya menurunkan infeksi kecacingan dan anemia serta meningkatkan status gizi pada balita gizi buruk yang mendapat PMT-P antara lain dengan pemberian obat cacing dan suplementasi sirup Fe + vitamin C.

Tujuan: Mengetahui pengaruh pemberian obat cacing, suplemen sirup Fe, dan vitamin $C$ terhadap peningkatan kadar Hb dan status gizi balita gizi buruk penerima PMT-P.

Metode: Jenis penelitian adalah eksperimental dengan rancangan faktorial. Sasaran penelitian adalah balita gizi buruk usia 1-3 tahun di Kota Kupang. Jumlah sampel sebanyak 128 anak dibagi dalam 4 kelompok perlakuan. Perlakuan obat cacing pirantel pamoat $125 \mathrm{mg}(n=32)$, sirup $\mathrm{Fe}+$ vitamin $C(n=32)$, obat cacing, sirup Fe+ vitamin $C(n=32)$ dan plasebo (n=32). Pengukuran kadar hemoglobin dengan "HemoCue", infeksi cacing diperiksa melalui tinja subjek untuk melihat adanya telur cacing. Analisis menggunakan uji T-test untuk mengetahui hubungan sebelum dan sesudah suplementasi dan uji ANOVA untuk melihat perbedaan efek suplementasi antar kelompok.

Hasil: Setelah 3 bulan, pemberian obat cacing sebelum intervensi berpengaruh signifikan terhadap status infeksi kecacingan pada kelompok obat cacing dan kelompok obat cacing, sirup Fe + vitamin C. Peningkatan kadar hemoglobin antarkelompok yang tertinggi adalah pada kelompok obat cacing, sirup Fe dan vitamin $C$ dengan ratarata kenaikan sebesar 1,2 g/dL. Rata-rata kenaikan berat badan antar kelompok sebesar 0,3 kg. Peningkatan nilai Z-score berpengaruh signifikan terhadap indek BB/U dan BB/TB.
\end{abstract}

Kesimpulan: Peningkatkan kadar hemoglobin berpengaruh signifikan terhadap perubahan peningkatan status gizi antarkelompok suplementasi.

KATA KUNCI: obat cacing, sirup Fe + vitamin C, kadar hemoglobin, Z-score, status gizi

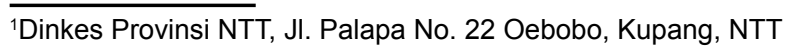

${ }^{2}$ STIKES Alma Ata Yogyakarta Prodi S1 Gizi, Jl. Ringroad Barat Daya No. 1 Tamantirto, Yogyakarta, email: hhadi@almaata.ac.id ${ }^{3}$ RSUP Dr. Sardjito Bagian IImu Kesehatan Anak, Jl. Kesehatan 1, Yogyakarta 


\section{PENDAHULUAN}

Tantangan utama dalam pembangunan suatu bangsa adalah membangun sumber daya manusia yang berkualitas sehat, cerdas, dan produktif. Pada tahun 2003, pencapaian pembangunan manusia yang diukur dengan indeks pembangunan manusia (IPM) belum menunjukkan hasil yang menggembirakan. IPM Indonesia berada pada peringkat 112 dari 174 negara, yang salah satu penyebabnya adalah rendahnya status gizi dan status kesehatan penduduk, antara lain masih tingginya angka kematian bayi sebesar 35/1.000 kelahiran hidup dan angka kematian balita sebesar $58 / 1.000$ kelahiran hidup (1). Lebih dari separuh kematian bayi dan balita disebabkan oleh keadaan gizi yang kurang baik dengan risiko meninggal pada anak gizi buruk 13 kali lebih besar dibandingkan anak normal. WHO memperkirakan bahwa $54 \%$ penyebab kematian bayi dan balita didasari oleh keadaan gizi anak yang buruk (2).

Di Provinsi Nusa Tenggara Timur, prevalensi balita gizi buruk dan gizi kurang selalu meningkat setiap tahun, yaitu $1,7 \%(2001), 1,8 \%$ (2002), 4,0\% (2003), 3,2\%(2004); dan 3,3\% pada tahun 2005. Di antara seluruh kasus gizi buruk, sebanyak 297 kasus merupakan gizi buruk dengan kelainan klinis marasmus, 1 anak kwashiorkor, dan 4 anak marasmus kwashiorkor (3).

Penatalaksanaan diet atau realementasi merupakan salah satu cara penanggulangan bagi balita gizi buruk yang selama ini telah dilakukan oleh pemerintah yaitu berupa pemberian makanan tambahan-pemulihan (PMT-P) selama 3 sampai 4 bulan atau 90 sampai 120 hari yang dampaknya telah terbukti dapat menurunkan angka prevalensi gizi buruk yaitu $10,1 \%$ pada tahun $1998,8,1 \%$ tahun 1999 , dan $6,3 \%$ tahun 2001 (4). PMT yang diberikan khusus di negara berkembang sangat baik jika difortifikasi dengan zat gizi mikro terutama zat besi, zinc, dan vitamin C (5).

Selain masalah gizi pada anak balita, prevalensi anemia gizi besi juga sangat tinggi yang berdasarkan SKRT (survei kesehatan rumah tangga) 2001 pada balita usia 0-5 tahun sebesar $48,1 \%(6)$, sedangkan berdasarkan survei cepat yang dilaksanakan tahun 2004, di NTT prevalensi anemia pada balita adalah $62,6 \%$. Selain asupan makanan yang mengandung zat besi masih rendah, penyebab lain tingginya anemia pada balita adalah infeksi kecacingan dan hal ini meningkat dengan memburuknya keadaan gizi. Insidensi tertinggi kasus tersebut terdapat pada golongan umur 1-3 tahun, sesuai prevalensi puncak KEP, anak-anak yang sedang menderita infeksi umumnya kadar hemoglobinnya lebih rendah (7).

Prevalensi kecacingan untuk jenis cacing Ascaris dan Trichuris pada balita di Joglo, Jakarta adalah $73,2 \%$ dan $60,9 \%$ (8). Beberapa penelitian telah membuktikan efek dari interaksi beberapa zat gizi mikro antara lain zat besi yang terbukti dapat memperbaiki selera makan, pertumbuhan anak, serta menurunkan prevalensi anemia.
Konsumsi zat besi sebaiknya dibarengi dengan vitamin $C$ karena penyerapan zat besi menjadi lebih mudah.

Berdasarkan uraian di atas, peneliti ingin mengetahui apakah pemberian obat cacing dan suplementasi sirup besi dan vitamin $C$ dapat meningkatkan kadar hemoglobin dan status gizi balita gizi buruk yang mendapat PMT-P di Kota Kupang, Provinsi Nusa Tenggara Timur.

\section{BAHAN DAN METODE}

Jenis penelitian adalah eksperimental dengan rancangan faktorial (factorial design) yang dibagi dalam empat kelompok perlakuan yaitu kelompok I (PMT dan plasebo), kelompok II (PMT dan obat cacing), kelompok III (PMT dan suplementasi sirup Fe $30 \mathrm{mg}$ + vitamin C $40 \mathrm{mg}$ ), dan kelompok IV (PMT dan suplementasi obat cacing, sirup Fe $30 \mathrm{mg}$ + vitamin C $40 \mathrm{mg}$ ) yang dilaksanakan di Kota Kupang, Provinsi Nusa Tenggara Timur dengan teknik double blinding.

Populasi penelitian adalah anak balita usia 1-3 tahun dengan status gizi buruk berdasarkan berat badan (BB) terhadap umur antara <-3 SD dari tabel WHO-NCHS, tidak sedang dirawat, bersedia ikut serta dalam penelitian, dan kadar $\mathrm{Hb}$ 8-9 g/dL. Sampel dipilih dengan metode randomisasi dengan bantuan tabel acak digunakan besar blok dipakai keseimbangan setiap delapan sampel.

Besar sampel ditentukan berdasarkan rumus Lemeshow et al. (9) dengan standar deviasi BB 0,7 dan perbedaan mean BB sebelum dan sesudah suplementasi adalah 0,6, sehingga total sampel sebesar 29 dengan droup out jumlah sampel menjadi 32 anak per kelompok, maka jumlah sampel keseluruhan adalah 128 anak. Variabel terikat dalam penelitian ini kadar hemoglobin dan status gizi, sedangkan variabel bebas adalah obat cacing dan sirup $\mathrm{Fe}+$ vitamin $\mathrm{C}$.

Jenis data meliputi data primer antara lain: identitas subjek, karakteristik keluarga, hasil pemeriksaan kadar $\mathrm{Hb}$, infeksi kecacingan, pengukuran antropometri yang meliputi BB dan tinggi badan (TB), dan kepatuhan minum suplementasi sirup $\mathrm{Fe}+$ vitamin $\mathrm{C}$. Pemeriksaan kadar hemoglobin menggunakan HemoCue-B Hemoglobin photometer (HemoCue Inc, Angelholm, Sweden) dan pemeriksaan infeksi kecacingan dilakukan di laboratorium puskesmas. Kadar $\mathrm{Hb}$ dan infeksi kecacingan diperiksa sebanyak 2 kali yaitu pada awal penelitian dan pada akhir penelitian, sedangkan BB dan TB dilakukan setiap bulan bersamaan dengan pengambilan PMT-P di 6 puskesmas yang menjadi sasaran penelitian.

Sebelum pemberian suplementasi, subjek terlebih dahulu diberi obat cacing sesuai dengan kelompok yang telah ditentukan dan frekuensi minum suplementasi sirup $\mathrm{Fe}+$ vitamin $\mathrm{C}$ adalah 3 kali seminggu selama 3 bulan. Kepatuhan minum suplementasi dilihat dari checklist yang diberi tanda silang $(\mathrm{x})$, botol obat yang harus dibawa pada 
saat pengambilan PMT-P, dan pengukuran antropometri setiap bulan sesuai jadwal yang telah ditentukan tiap puskesmas.

Analisis data dilakukan dengan bantuan software komputer untuk penentuan status gizi dan asupan nilai gizi energi, protein, vitamin $\mathrm{C}$, dan zat besi. Analisis analitik untuk menguji hipotesis beda antar kelompok menggunakan uji ANOVA dan Kruskal Wallis. Pengaruh suplementasi terhadap kadar hemoglobin dan status gizi tiap kelompok menggunakan uji paired T-test.

\section{HASIL DAN BAHASAN}

\section{Karakteristik subjek}

Karakteristik subjek awal dapat dilihat pada Tabel 1 yang meliputi: jenis kelamin, umur, kadar hemoglobin, status kecacingan, BB $(\mathrm{kg})$, TB $(\mathrm{cm})$, status gizi (indeks
$B B / U, T B / U$, dan BB/TB), pendidikan ayah dan ibu, jenis pekerjaan ayah dan ibu, dan asupan energi, protein, vitamin $\mathrm{C}$, dan zat besi.

Berdasarkan Tabel 1, status gizi yang meliputi BB, $\mathrm{TB}$, dan Z-score BB/U, TB/U, dan BB/TB rata-rata berada di bawah standar WHO-NCHS. Semua subjek berstatus gizi buruk dengan score $Z \geq-3$ SD, 69,5\% pendidikan ayah lebih rendah atau sama dengan SLTP, $79,7 \%$ pendidikan ibu lebih rendah atau sama dengan SLTP, dan 89,8\% pekerjaan ayah bukan pegawai dan $95,3 \%$ ibu tidak bekerja atau sebagai ibu rumah tangga. Asupan zat gizi energi, protein, vitamin $\mathrm{C}$, dan zat besi semua kelompok tidak memenuhi standar kecukupan untuk golongan umur 1-3 tahun (10).

Seluruh variabel yang diukur pada keempat kelompok tidak menunjukkan perbedaan yang nyata $(p>0,05)$. Hal ini membuktikan bahwa keempat kelompok telah diambil secara acak dengan baik dari populasi yang sama,

Tabel 1. Karakteristik subjek penelitian

\begin{tabular}{|c|c|c|c|c|c|}
\hline \multirow{2}{*}{ Variabel } & \multicolumn{4}{|c|}{ Kelompok perlakuan } & \multirow{2}{*}{$\underset{(s i g)}{p}$} \\
\hline & Plasebo & Obat cacing & Fe +vitamin C & Obat cacing, $\mathrm{Fe}+$ vitamin $\mathrm{C}$ & \\
\hline Kadar $\mathrm{Hb}$ awal & $8,74 \pm 0,74$ & $9,2 \pm 1,04$ & $9,1 \pm 1,03$ & $9,1 \pm 0,84$ & $0,192^{\mathrm{a}}$ \\
\hline \multicolumn{6}{|l|}{ Kecacingan } \\
\hline Positif & $18(56,3 \%)$ & $22(68,8 \%)$ & $20(62,5 \%)$ & $20(62,5 \%)$ & \multirow[t]{2}{*}{$0,785^{\mathrm{b}}$} \\
\hline Negatif & $14(43,8 \%)$ & $10(31,3 \%)$ & $12(37,5 \%)$ & $12(37,5 \%)$ & \\
\hline \multicolumn{6}{|l|}{ Jenis kelamin } \\
\hline Laki-laki & $17(13,3 \%)$ & $14(10,9 \%)$ & $15(11,7 \%)$ & $16(12,5 \%)$ & \multirow[t]{2}{*}{$0,848^{b}$} \\
\hline Perempuan & $15(11,7 \%)$ & $18(14,1 \%)$ & $18(14,1 \%)$ & $15(11,7 \%)$ & \\
\hline \multicolumn{6}{|l|}{ Umur } \\
\hline $12-24$ bln & $16(12,5 \%)$ & $15(11,7 \%)$ & $17(13,3 \%)$ & $21(16,4 \%)$ & \multirow{2}{*}{$0,348^{b}$} \\
\hline 25-36 bln & $16(12,5 \%)$ & $17(13,3 \%)$ & $16(12,5 \%)$ & $10(7,8 \%)$ & \\
\hline BB awal (kg) & $8,0 \pm 1,0$ & $7,9 \pm 1,0$ & $7,9 \pm 0,9$ & $7,8 \pm 1,0$ & $0,474^{a}$ \\
\hline TB awal (kg) & $76,3 \pm 6,0$ & $76,4 \pm 5,0$ & $75,1 \pm 5,9$ & $74,9 \pm 4,6$ & 0,574 a \\
\hline \multicolumn{6}{|l|}{ Status gizi (Z-score) } \\
\hline $\mathrm{BB} / \mathrm{U}(\mathrm{WAZ})$ & $-3,4 \pm 0,38$ & $-3,5 \pm 0,53$ & $-3,5 \pm 0,57$ & $-3,5 \pm 0,57$ & $0,574^{a}$ \\
\hline TB/U (HAZ) & $-2,8 \pm 1,04$ & $-3,2 \pm 1,33$ & $-3,5 \pm 1,22$ & $-3,0 \pm 1,46$ & $0,220^{a}$ \\
\hline $\mathrm{BB} / \mathrm{TB}(\mathrm{WHZ})$ & $-2,3 \pm 0,62$ & $-2,31 \pm 0,62$ & $-2,1 \pm 0,79$ & $-2,4 \pm 0,83$ & $0,269^{a}$ \\
\hline \multicolumn{6}{|l|}{ Pekerjaan ayah } \\
\hline Bukan pegawai & $27(23,5 \%)$ & $29(25,2 \%)$ & $31(27,0 \%)$ & $28(24,3 \%)$ & \multirow{2}{*}{$0,640^{b}$} \\
\hline Pegawai & $5(38,5 \%)$ & $3(23,1 \%)$ & $2(15,4 \%)$ & $3(23,1 \%)$ & \\
\hline \multicolumn{6}{|l|}{ Pekerjaan ibu } \\
\hline Ibu rumah tangga & $31(96,9 \%)$ & $30(93,8 \%)$ & $31(96,9 \%)$ & $30(93,8 \%)$ & \multirow{2}{*}{$0,873^{b}$} \\
\hline Bekerja & $1(3,1 \%)$ & $2(6,3 \%)$ & $1(3,1 \%)$ & $2(6,3 \%)$ & \\
\hline \multicolumn{6}{|l|}{ Pendidikan ayah } \\
\hline$\leq$ SLTP & $19(22,1 \%)$ & $24(27,9 \%)$ & $22(25,6 \%)$ & $21(24,4 \%)$ & \multirow{2}{*}{$0,619^{b}$} \\
\hline$\geq S L T A$ & $13(31,0 \%)$ & $8(19,0 \%)$ & $11(26,2 \%)$ & $10(23,8 \%)$ & \\
\hline \multicolumn{6}{|l|}{ Pendidikan ibu } \\
\hline SSLTP & $25(78,1 \%)$ & $28(87,5 \%)$ & $25(78,1 \%)$ & $24(75,0 \%)$ & \multirow{2}{*}{$0,629^{b}$} \\
\hline$\geq$ SLTA & $7(21,9 \%)$ & $4(12,5 \%)$ & $7(21,9 \%)$ & $8 \quad(25,0 \%)$ & \\
\hline Asupan zat gizi & $524,8 \pm 207,0$ & $503,4 \pm 203,3$ & $546,9 \pm 191,4$ & $476,8 \pm 162,8$ & $0,518^{c}$ \\
\hline Energi (kal) & $17,7 \pm 8,82$ & $16,3 \pm 6,93$ & $19,6 \pm 8,52$ & $15,9 \pm 8,22$ & $0,290^{c}$ \\
\hline Protein (gram) & $9,7 \pm 8,99$ & $8,6 \pm 6,20$ & $9,9 \pm 9,3$ & $7,7 \pm 6,78$ & $0,832^{c}$ \\
\hline $\begin{array}{l}\text { Vitamin C } \\
\text { Fe }\end{array}$ & $2,2 \pm 1,69$ & $1,9 \pm 1,26$ & $2,4 \pm 2,05$ & $1,6 \pm 1,09$ & $0,599^{c}$ \\
\hline
\end{tabular}

a Uji Anova

b Uji Chi-Square

- Uji Kruskal Wallis 
Tabel 2. Rata-rata perubahan nilai dari variabel yang diukur antarkelompok suplementasi

\begin{tabular}{lccccc}
\hline \multicolumn{1}{c}{ Variabel } & Plasebo & Obat cacing & Fe+vitamin C & $\begin{array}{c}\text { Obat cacing, } \\
\text { Fe + vitamin C }\end{array}$ & p \\
\hline \% kepatuhan & $96,9 \%$ & $100 \%$ & $81,3 \%$ & $84,4 \%$ & $100 \%$ \\
\% infeksi cacing & $43,8 \%$ & $100 \%$ & $37,5 \%$ & $2,07 \pm 0,95$ & $0,000^{*}$ \\
Kadar Hb (g/dl) & $0,87 \pm 0,85$ & $1,09 \pm 0,84$ & $1,07 \pm 1,23$ & $0,50 \pm 0,31$ & $0,000^{*}$ \\
BB (kg) & $0,19 \pm 0,27$ & $0,24 \pm, 0,31$ & $0,31 \pm 0,28$ & $3,68 \pm 1,78$ & $0,000^{*}$ \\
TB (cm) & $2,93 \pm 1,56$ & $3,59 \pm 2,85$ & $3,60 \pm 2,31$ & $1,04 \pm 0,62$ & 0,649 \\
Z-score (BB/U) & $0,53 \pm 0,58$ & $0,63 \pm 0,61$ & $0,99 \pm 1,05$ & $0,92 \pm 1,33$ & $0,012^{*}$ \\
Z-score (TB/U) & $0,69 \pm 1,22$ & $1,11 \pm 1,36$ & $1,32 \pm 0,77$ & $-0,68 \pm 1,15$ & 0,191 \\
Z-score(BB/TB) & $-0,27 \pm 0,62$ & $-0,13 \pm 0,79$ & $-0,15 \pm 0,63$ & & $0,032^{*}$ \\
\hline
\end{tabular}

* signifikan $(p<0,05)$

Tabel 3. Jenis infeksi kecacingan sebelum suplementasi

\begin{tabular}{lcc}
\hline \multicolumn{1}{c}{ Jenis cacing } & Jumlah positif & Persentase (\%) \\
\hline Ascaris lumbricoides & 37 & 46,3 \\
Trichuris trichiura & 4 & 5,0 \\
Cacing tambang & 36 & 45,0 \\
Ascaris + Cacing tambang & 3 & 3,8 \\
\hline
\end{tabular}

sehingga faktor pengganggu yang dapat mengakibatkan bias dalam penelitian ini telah dikendalikan dengan baik.

Hasil pengukuran dari variabel yang disajikan adalah berupa besarnya perubahan awal dan akhir suplementasi selama penelitian. Perbedaan perubahan antarkelompok ini dapat dilihat pada Tabel 2.

\section{Kepatuhan minum suplementasi}

Kepatuhan minum suplementasi antarkelompok yang tertinggi adalah pada kelompok obat cacing $(100 \%)$ dan yang terendah adalah pada kelompok sirup $\mathrm{Fe}+$ vitamin C. Dari keempat kelompok tersebut, kelompok yang suplementasinya benar-benar mengandung sirup $\mathrm{Fe}+$ vitamin $\mathrm{C}$ adalah pada 2 kelompok saja yaitu kelompok sirup $\mathrm{Fe}+$ vitamin $\mathrm{C}$ dan kelompok obat cacing, sirup $\mathrm{Fe}+$ vitamin $\mathrm{C}$, sedangkan 2 kelompok lainnya suplementasi diberikan berupa sirup mocca yang merupakan plasebo dan obat cacing. Persentase kepatuhan tertinggi terdapat pada kelompok plasebo dan obat cacing karena rasa yang ditimbulkan lebih enak (tidak mengandung preparat besi). Kadar hemoglobin meningkat sesuai dengan peningkatan kepatuhan dan bermakna jika kepatuhan mencapai nilai $\geq 80 \%$ (11).

\section{Prevalensi infeksi kecacingan}

Subjek yang positif terinfeksi kecacingan berkurang pada akhir penelitian dan secara statistik ada pengaruh yang signifikan $(p<0,05)$, artinya pemberian obat cacing dapat menurunkan infeksi kecacingan pada kelompok yang mendapat obat cacing yaitu kelompok obat cacing dan kelompok suplementasi obat cacing, sirup $\mathrm{Fe}+$ vitamin C. Kelompok plasebo dan sirup $\mathrm{Fe}+$ vitamin $\mathrm{C}$, pada akhir penelitian memiliki persentase infeksi kecacingan yang tetap karena subjek pada awal penelitian tidak diberi obat cacing, tetapi setelah penelitian berakhir subjek yang termasuk dalam kelompok plasebo dan sirup Fe + vitamin $C$ segera diberi obat cacing. Pemberian obat cacing dapat menghilangkan infeksi kecacingan pada balita yang diberi obat cacing (12).Adapun jenis cacing yang banyak menginfeksi dapat dilihat pada Tabel 3.

\section{Perubahan kadar hemoglobin}

Perlakuan pada penelitian ini terbukti secara statistik mampu meningkatkan kadar hemoglobin subjek penelitian dan peningkatan yang tertinggi dapat dilihat pada kelompok suplementasi sirup $\mathrm{Fe}+$ vitamin $\mathrm{C}$ yaitu sebesar $2,07 \mathrm{~g} / \mathrm{dL}$ $(p<0,05)$. Absorbsi zat besi dalam bentuk nonheme meningkat empat kali lipat bila ada vitamin $C$ dan vitamin $C$ juga berperan dalam memindahkan besi dari transferin di dalam plasma ke feritin hati (13).Bahan makanan yang berasal dari protein hewani, asam fitat, dan asam askorbat mampu membantu absorbsi zat besi dalam tubuh dengan baik (14). Hasil penelitian mengenai zat besi yang diminum bersama dengan makanan pokok dan vitamin $\mathrm{C}$ atau pepaya terbukti mampu meningkatkan penyerapan besi menjadi 47,7\% (15).

Pada keempat kelompok suplementasi, setelah dilakukan multiple comparation dengan menggunakan analisis LSD (least significant difference) atau beda nyata terkecil menunjukkan hasil kelompok suplementasi obat cacing, sirup $\mathrm{Fe}+$ vitamin $\mathrm{C}$ mampu menaikkan kadar hemoglobin darah lebih besar dibanding kelompok yang lain (Tabel 4). Peningkatan kadar hemoglobin membuktikan bahwa PMT-P yang diberikan dengan ditambah obat cacing, zat besi, dan vitamin $C$ daya serapnya lebih baik dibanding kelompok yang lain (16).

\section{Perubahan BB dan TB}

BB dan TB mengalami peningkatan pada akhir suplementasi. BB mengalami peningkatan yang cukup 
Tabel 4. Perbandingan perbedaan peningkatan kadar hemoglobin tiap kelompok

\begin{tabular}{llcccc}
\hline \multirow{2}{*}{ Referens } & \multicolumn{1}{c}{ Kelompok perlakuan } & Perbedaan & \multirow{2}{*}{ Sig } & \multicolumn{2}{c}{$\mathbf{9 5 \% ~ C l ~}$} \\
\cline { 3 - 6 } & mean & & Lower & Upper \\
\hline Plasebo & Obat cacing & $-0,21$ & 0,359 & $-0,69$ & 0,25 \\
& Sirup Fe+vitamin C & $-0,01$ & 0,684 & $-0,57$ & 0,37 \\
Obat cacing & Obat cacing, Sirup Fe+vitamin C & 1,15 & $\left.0,000^{*}\right)$ & 1,62 & 0,68 \\
& Plasebo & 0,21 & 0,359 & $-0,25$ & 0,69 \\
Sirup Fe & Sirup Fe+vitamin C & 0,12 & 0,609 & $-0,35$ & 0,59 \\
& Obat cacing, sirup Fe+ vitamin C & 0,93 & $\left.0,000^{*}\right)$ & 1,41 & $-0,46$ \\
& Plasebo & $-0,01$ & 0,68 & $-0,37$ & 0,57 \\
Obat cacing, & Obat cacing & $-0,12$ & 0,61 & $-0,59$ & 0,35 \\
Sirup Fe+ vitamin C & Obat cacing, sirup Fe+ vitamin C & 1,06 & $\left.0,00^{*}\right)$ & 1,53 & 0,58 \\
& Plasebo & 1,15 & $\left.0,00^{*}\right)$ & 0,68 & 1,62 \\
& Obat cacing & 0,93 & $\left.0,00^{*}\right)$ & 0,46 & 1,41 \\
\hline
\end{tabular}

* Signifikan $(p<0,05)$

besar pada bulan ketiga dengan peningkatan yang tertinggi adalah pada kelompok suplementasi obat cacing, sirup $\mathrm{Fe}+$ vitamin $\mathrm{C}$ yaitu sebesar $0,50 \mathrm{~kg}$ dan berdasarkan uji statistik hasilnya signifikan $(p<0,05)$. Hal ini berarti pemberian suplementasi berpengaruh terhadap peningkatan BB tetapi tidak berpengaruh secara signifikan terhadap peningkatan TB hal ini disebabkan TB tidak dapat mengalami perubahan dalam waktu yang relatif singkat. Peningkatan TB dalam waktu 1 tahun pada anak usia 1-3 tahun baru akan bermakna untuk mengubah status gizi jika sudah $>12 \mathrm{~cm}$ (15). Jika dibandingkan dengan umur, akan menggambarkan status gizi dimasa lalu. Selain dipengaruhi pemberian suplementasi, kenaikan BB pada subjek juga disebabkan asupan zat gizi yang diperoleh dari PMT-P yang diberikan selama 3 bulan.

Pertambahan BB ini masih belum dianggap baik karena belum mencapai 50 gram per minggu sesuai dengan acuan dari Depkes RI tentang pedoman tata laksana anak gizi buruk. Oleh karena itu, pada penelitian ini diharapkan kenaikan BB selama 3 bulan atau 12 minggu dapat mencapai 600 gram dan kriteria ini hampir terpenuhi oleh anak gizi buruk pada kelompok suplementasi obat cacing, sirup Fe + vitamin C. Fortifikasi dan suplementasi pada balita gizi buruk yang mendapat makanan tambahan dapat meningkatkan BB dan TB lebih baik dibanding PMT-P yang tidak mendapat fortifikasi (17). Rata-rata peningkatan BB subjek setelah suplementasi dapat dilihat pada Gambar 1.

\section{Perubahan Z-score}

Peningkatan Z-score hanya signifikan pada indek $\mathrm{BB} / \mathrm{U}$ dan BB/TB $(p<0,05)$. Hal ini membuktikan bahwa pada balita gizi buruk yang diberi PMT-P dan suplementasi obat cacing dan sirup $\mathrm{Fe}+$ vitamin $\mathrm{C}$ dapat berpengaruh dalam meningkatkan status gizi balita dari gizi buruk menjadi gizi kurang atau normal dan dari sangat kurus menjadi kurus atau normal.

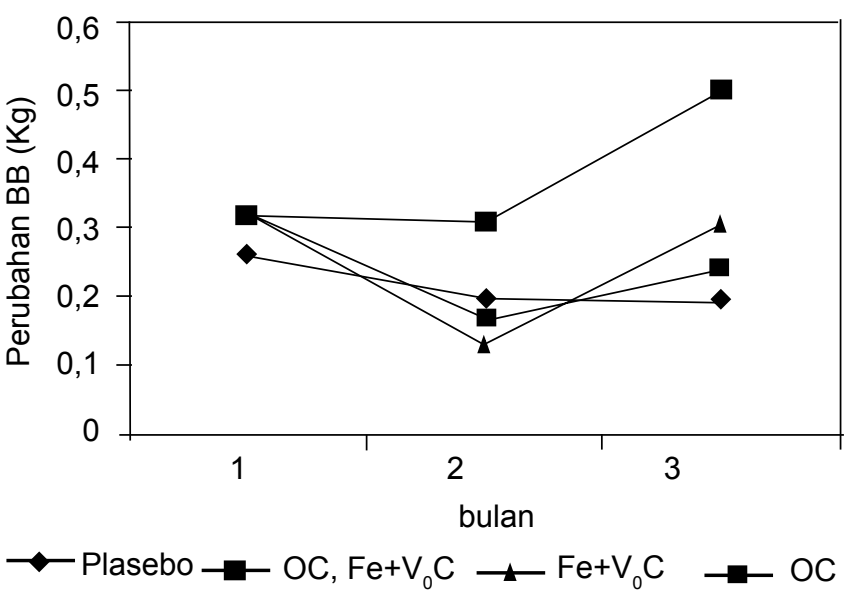

Gambar 1. Rata-rata peningkatan berat badan sesudah suplementasi

Peningkatan BB dapat dilihat pada Gambar 1. Status gizi subjek antar kelompok akan lebih baik jika diukur berdasarkan indek BB/TB karena indek ini sangat sensitif atau peka terhadap perubahan status gizi dan dapat menggambarkan keadaan kurang gizi akut saat ini. Selain itu, program penanggulangan gizi buruk dengan cara pemberian intervensi yang memerlukan waktu relatif singkat sebaiknya menggunakan indek BB/TB sebagai indikator keberhasilannya. Sementara itu, indek BB/U merupakan parameter yang sangat labil karena massa tubuh sangat sensitif terhadap perubahan yang mendadak seperti terserang infeksi, menurunnya nafsu makan, atau menurunnya jumlah makanan yang dikonsumsi, sehingga indeks BB/U dianggap sebagai current nutritional status (18).

Penambahan suplementasi microencapsulated ferrous fumarate dengan asam askorbat pada makanan tambahan yang diberikan kepada balita gizi buruk dapat meningkatkan pertumbuhan linier balita dan secara signifikan berpengaruh terhadap nilai Z-score TB/U (19). 


\section{KESIMPULAN DAN SARAN}

Pemberian obat cacing mempunyai pengaruh yang signifikan terhadap infeksi kecacingan, peningkatan kadar hemoglobin, dan status gizi balita. Suplementasi obat cacing, sirup $\mathrm{Fe}+$ vitamin $\mathrm{C}$ mempunyai pengaruh yang signifikan terhadap peningkatan kadar hemoglobin dan status gizi balita dan pengaruh ini berbeda nyata antarkelompok.

Sebagai saran agar pemberian PMT-P lebih efektif pada balita gizi buruk, sebaiknya sebelum pelaksanaan PMT-P dimulai balita yang selama 6 bulan terakhir tidak pernah minum obat cacing diberi obat cacing terlebih dahulu karena infeksi kecacingan sangat berpengaruh terhadap kenaikan kadar hemoglobin dan status gizi anak. Suplementasi sirup Fe dan vitamin C yang diberi flavor mocca dapat menjadi alternatif yang baik untuk mengurangi rasa khas preparat besi yang tidak disukai balita (amis, getar di lidah, dan meninggalkan bekas atau warna hitam digigi). Pemeriksaan infeksi kecacingan pada balita perlu dilakukan secara rutin untuk mengetahui prevalensi kecacingan pada balita di Provinsi NTT, karena selain terinfeksi cacing tambang, Ascaris lumbricoides, dan Trichuris trichuria, diduga balita di Provinsi NTT juga terinfeksi cacing pita. Untuk mencegah infeksi kecacingan, kebersihan lingkungan dan perorangan perlu diperhatikan memasak makanan maupun air minum dengan pemanasan yang cukup, membiasakan cuci tangan sebelum makan, dan penggunaan alas kaki baik di dalam maupun di luar rumah.

\section{RUJUKAN}

1. Azwar A. Kecenderungan masalah gizi dan tantangan di masa datang. Jakarta: Pertemuan Advokasi Program Perbaikan Gizi Menuju Keluarga Sadar Gizi; 2004.

2. Direktorat Bina Gizi Masyarakat, Depkes RI. Petunjuk teknis tata laksana anak gizi buruk buku II. Jakarta: Depkes RI; 2003.

3. Dinkes Provinsi NTT. Laporan program seksi kewaspadaan pangan dan gizi tahun 2005. Kupang: Dinkes Provinsi NTT; 2005.

4. Dinkes Provinsi NTT. Profil Kesehatan Provinsi NTT Tahun 2005. Kupang: Dinkes Provinsi NTT; 2005.

5. Gibson RS,Ferguson EL, Lehrfeld J. Complementary foods for infant feeding in developing countries: Their Nutrient Adequacy and Improvement. Eur J Clin Nutr 1998;(52):764-70.

6. Pudjiadi S. Ilmu gizi klinis pada anak. Edisi ke Empat. Jakarta: Gaya Baru; 2002.
7. Ismid I, Margono S. Kebersihan pribadi, sanitiasi lingkungan dan status gizi anak sekolah yang menderita askariasis. Majalah Parasitologi Indonesia 1989; 2:97-102.

8. Hadi H. Meningkatkan kepatuhan minum tablet besi ibu hamil: pentingnya peranan suami. Berita Kedokteran Masyarakat 2001;17(2):51-62.

9. Lemeshow S, Hosmer DW, Klar J, Lwanga SK. 1990. Adequacy of Sample Size in Health Studies. (Terjemahan) Pramono D, Kusnanto H. Yogyakarta: Gadjah Mada University Press; 1997.

10. Kartono D, Soekarti M. Angka kecukupan mineral: besi, yodium, seng, mangan, selenium. Prosiding Widyakarya Nasional Pangan dan Gizi VIII; 2004 May 17-19; Jakarta; 2004. p.393-416.

11. Almatsier S. Prinsip dasar ilmu gizi. Jakarta: PT Gramedia Pustaka Utama; 2004.

12. Widayati P. Penyakit soil transmitted helminths pada murid Sekolah Dasar Sungai Tiung I Kelurahan Cempaka, Banjarbaru. Berkala Kedokteran 2001;1(1):23-9.

13. Davidson L, Kastenmeyer P, Szajewska H, Hurrel RF, Barclay D. Iron bioavailability in infants from an infant cereal fortified with ferric pyrophosphate or ferrous fumarate. Am J Clin Nutr 2000;(71):1597-602.

14. Almasyhuri M, Saidin, Sukati. Penyerapan ferro sulfas yang diminum bersamaan dengan makanan pokok beras, jagung serta singkong dengan vitamin $C$ atau pepaya: suatu uji penyerapan secara in-vitro. Buletin Penelitian Gizi \& Makanan 1998;(21):125-30.

15. Reddy MB, Hurrel RF, Cook JD. Estimation of nonheme-iron bioavailability from meal composition. Am J Clin Nutr 2000;(71):937-43.

16. Arisman. Gizi dalam daur kehidupan. Jakarta: EGC; 2004.

17. Gibson S, Rosalin. Principles of nutritional assessment. New York: Oxfod University Press; 1990.

18. Simpore J, Kabore F, Zongo F, Dansou D, Bere $A$, Pignatelli $S$, et al. Nutrition rehabilitation of undernourished children utilizing spiruline and misola. [Internet], Januari 2006[Accessed 20 Juni 2006];5(3):1-7. Available from: http://www.nutritionj. com>.

19. Zlotkin S, Arthur P, Antwi YK, Yeung G. Clinical nutrition: treatment of anemia with microencapsulated ferrous fumarate plus ascorbic acid supplied as sprinkles to complementary (weaning) foods. Am J Clin Nutr 2000;(5):791-5. 